\title{
How the Jewish Intelligentsia Created the Jewishness of the Jewish Hero: The Soviet Yiddish Press ${ }^{1}$
}

\section{Arkadi Zeltser}

In June 1943, Eynikayt, the Yiddish newspaper of the Jewish Anti-Fascist Committee (JAC), referred to Major Tsezar Kunnikov, a fallen commander of a marine unit, as a "Jewish hero" (yidish held). ${ }^{2}$ The appearance of this term was not a case of negligence on the part of an editor or censor. It was the expression of the views of the Soviet Jewish intelligentsia and in full accord with the practices allowed by the Soviet regime. The preceding years had already seen articles that dealt with various aspects of the ethnic identity of Jews in the Red Army during the Second World War. ${ }^{3}$ In this context it remained to be seen how the ethnically oriented Soviet Jewish intelligentsia would relate to Jewish heroes.

Soviet propaganda devoted considerable efforts to securing maximum support for the war against Germany, both among the Soviet population and abroad. For this purpose, two basic means were employed: 1) inculcating hatred toward the enemy by spreading information about Nazi cruelty and thus creating a negative image of the enemy, and 2) creating a positive image of the Soviet hero fighting for his people, his country, and all of humanity (providing a positive model to identify with). In the spring of 1942, the Soviet Information Bureau (Sovinformbiuro) established five anti-fascist committees-a pan-Slavic one to attract Slavs, and ones aimed at women, scientists, youth, and Jews ${ }^{4}$-in order to try to gain public support abroad for the war effort. The main tool of their influence-seeking was propaganda texts sent to foreign telegraph agencies, newspaper offices, as well as anti-fascist radio broadcasts and periodical publications based in the Soviet Union itself. Among the latter was the JAC's Yiddish-language Eynikayt, which began to 
appear in June $1942 .{ }^{5}$ According to JAC statements, the newspaper was mainly targeted at the "mass Jewish reader brought up and reeducated by the Soviet regime," as well as readers from the territories annexed to the USSR, "who had not attended the Soviet school of life." 6 During the war a maximum of three thousand copies of the ten thousand copies printed were sent abroad, while the remaining seven thousand were distributed in various cities of the USSR, including two thousand that were sold in stores rather than by subscription. ${ }^{7}$

The very appearance of information in Yiddish in the newspaper spurred ethnic identification among the heroes and readers of the articles and encouraged interest in Jewish topics. As members of the Lithuanian Division of the Red Army cited by JAC activists in regard to the Eynikayt, "It contains

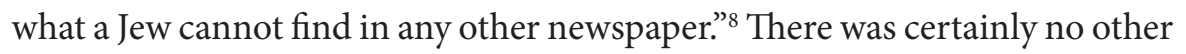
publication in the USSR in which the 18-year-old Hero of the Soviet Union Chaim (Efim) Diskin, who came from the Crimean Jewish settlement of Kadima and was a student of the Moscow Institute of Philosophy, Literature, and History before the war, could write what he did in November 1942: "I am proud to know that I am a son of the great Jewish people [groysn yidishn folk] that has given to the world such great people as Marx and Heine, Sholem Aleichem and Einstein, Sverdlov and Kaganovich, Spinoza and Peretz.... Our people are mighty and talented and the fascist monsters will never destroy us or force us to our knees."

Many writers in Eynikayt-especially Shakhno Epshteyn, ${ }^{10}$ the Soviet Yiddish journalist who was Eynikayt's editor from 1942 to 1945 and also senior secretary of the JAC, and Itsik Fefer, ${ }^{11}$ his assistant at the newspaper, the Yiddish poet and journalist-were well aware of the propagandistic goals they were appointed to pursue, and in many ways they fulfilled this propagandistic task. Nevertheless, within the framework of Soviet political censorship (and self-censorship), the Soviet Jewish Yiddish-language intelligentsia, which was largely composed of veteran Soviet Yiddish littérateurs (poets Peretz Markish, Leyb Kvitko, and Shmuel Halkin, and the prose writers David Bergelson, Shmuel Persov, et al.), attempted to express their own ideas in the JAC newspaper and convey their concern about the fate of their fellow Jews to their usual readers both in the Soviet Union and abroad. ${ }^{12}$ Due to the efforts of its writers and editors, for the entirety of its existence Eynikayt was both Soviet and Jewish, not simply Soviet, as was intended by the segment of the Party bureaucracy that criticized the JAC for failing to publish more non-Jewish material in its newspaper. ${ }^{13}$ 
The concerns of the Yiddish intelligentsia about the reputation of the Jews during the war was nowhere as strongly expressed as in Eynikayt's articles about Jewish heroism. In this context four questions arise: 1) Were there any new approaches in the treatment of the topic of heroism during the war as opposed to the prewar period? 2) How did the ethnic component in the treatment of heroism change during the war? 3) Did the Soviet Jewish intelligentsia deal with the topic of heroism in the Yiddish press in strict conformity with the norms set by the Soviet authorities, or did they attempt to express their own views about Jewish national problems? And 4) how did the Yiddish-language intelligentsia create the Jewishness of Jewish heroes?

\section{Patriotic Narratives}

The image of the Jewish hero was in many ways formed in correspondence with the reigning ideas of the heroic in the Soviet Union in general. In the second half of the 1930s, due to changes in both domestic and foreign policy in the USSR, propaganda espousing world revolution was replaced with that which espoused the cultivation of Soviet patriotism in various ethnic versions. Previous revolutionary heroes (like the Decembrists, Emel'ian Pugachev, and Stepan Razin) who in the 1920s had been hailed by the Mikhail Pokrovskii school of history, were replaced by the tsars and military leaders of ancient Rus', Muskovii, and the Russian Empire (like Aleksandr Nevskii, Ivan the Terrible, Kuzma Minin and Dmitrii Pozharskii, and Peter the Great). ${ }^{14}$ At the same time, during these years a balance was preserved between the new forms of etatism and Marxism-Leninism, between appealing to traditional ethnic heroes of the past and the idea of class struggle. In this situation, when a new emphasis was being placed on the history of the Russian people, it also became legitimate to appeal to the remote past of other ethnic groups. ${ }^{15}$

In the 1920s, Hirsh Lekert, a worker from Vilna who was executed for attempting to assassinate Governor-General Victor von Wahl in revenge for the humiliation of Jewish workers who had been arrested, was the symbol of Jewish heroism. During this decade, Soviet streets, enterprises, schools, and Jewish agricultural cooperatives were named after Lekert. Plays and even a film portrayed his life. The need at that time for an ethnically Jewish revolutionary hero was perceived to be so great (as was the case for other ethnic groups as well) that Soviet ideologists even ignored the fact that Lekert had been a member of the Bund (an early rival of the Bolsheviks) and that 
Bolshevik historiography condemned the kind of individual terrorist acts resorted to by Lekert. In the first half of the 1930s, the official attitude toward the Jewish Lekert changed, as it did toward revolutionary heroes of other ethnic groups. ${ }^{16}$

In 1937, Lazar Kaganovich, the Secretary of the Communist Party Committee of Moscow and a member of Stalin's inner circle, attended a performance at the Moscow State Yiddish Theater of the play "Boytre the Thief" by the Yiddish poet and dramatist Moyshe Kulbak. Kaganovich demanded that the theater's director change the repertoire by abandoning the depiction of shtetl Jews and turn instead to heroic images of the Jewish past, like the Maccabees, the leaders of the Jewish revolt in 160 BCE who rededicated the Temple; Bar Kochba, the leader of the Jews' revolt against Rome in $132 \mathrm{CE}$; or the creators of the Jewish present in Birobidzhan. The interference of such a high-ranking functionary provided legitimacy for turning to the heroic theme of historic Judea. ${ }^{17}$ Earlier under the Soviets such subject matter was problematic, since the images of the Maccabees and Bar Kochba had been popular in Zionist discourse. ${ }^{18}$ Kaganovich's dictum relieved the Jewish intelligentsia of the threat that they would be accused of being Jewish nationalists by other writers or by Party supervisors from the Propaganda Division of the Party's Central Committee.

In accordance with this new approach, Shmuel Halkin's adaptation of Goldfaden's play Bar Kochba, which was published in Moscow in 1939, was staged by the Moscow and Birobodzhan State Yiddish Theaters in the same year. In this play, Halkin, a prominent Yiddish poet and playwright who was well-known for his interest in the Jewish national past, completely fit his heroes into the transitional canon of that time. On the one hand, his heroes were national: the last words of Bar Kochba's beloved Pnina, killed by the Romans, are: "My last breath is for you, my people." ${ }^{19}$ On the other hand, the play corresponds to the Soviet approach to class: both Bar Kochba and Rabbi Akiva, the spiritual leader of the revolt against Rome, come from the lower classes (peasants), while Bar Kochba's main Jewish antagonist in the play, the pro-Roman Menashe, is a rich merchant. At this time, Soviet Jewish scholars also turned to ancient Jewish history, integrating into their research both class and ethnic approaches. ${ }^{20}$

In the historical discourse of the early war years, when the patriotism of the Soviet peoples (first of all that of the Russians) was increasing, the previous emphasis on class struggle was completely replaced by a stress on ethnicity. 
Already in the radio speech delivered by Viacheslav Molotov on June 22, 1941, following the invasion of the Soviet Union by German troops, one could note the reference to the historical tradition of the Russians repelling aggression. The current war was declared to be a patriotic one, using the term "otechestvennaia" ("for the fatherland"), which had been used for the Patriotic War of 1812 against Napoleon. In Stalin's speech delivered in Red Square on November 7, 1941, the Soviet leader evoked the images of the "great [Russian] ancestors" who should be emulated that day: Aleksandr Nevskii, Dmitrii Donskoi, Minin, Pozharskii, Aleksandr Suvorov, and Mikhail Kutuzov. In the effort to stir the public's patriotism, there were also increasing references to names that incarnated the pride of "the great Russian nation" (Stalin's term) in the field of culture, such as Pushkin, Tolstoy, Gorky, Chekhov, Tchaikovsky, and Glinka. ${ }^{21}$ This trend of extolling intellectual as well as military heroes of the past provided a model for other peoples, including the Jews. As a consequence, in order to evoke national pride, publications began to hail Jewish literary and philosophical figures whose works were particularly significant for Jewish culture (like Yehuda Halevi, Maimonides, Sholem Aleichem, and I. L. Peretz), Jews who made major contributions to universal knowledge (e.g. Marx, Spinoza, and Einstein), and famous Jewish Bolsheviks (like Iakov Sverdlov, Moisei Uritskii, and Lazar Kaganovich). This process of reviving ethnic heroes of the past and referring to non-Russian Bolshevik leaders, which was taking place among various Soviet nationalities, most likely increased ethnic pride among these peoples during the war years. ${ }^{22}$

The rejection of the basic Bolshevik postulate of the primacy of class was expressed in the rehabilitation of the term "narod" (people). In the 1920s, deviation from Lenin's principle that every nation consists of two nations - the exploiters and the exploited-was viewed as nationalism, and the term "narod" was symptomatic of this political error. However, starting in 1937-1938 "the great Russian people" ("velikii russkii narod") became a positive term in the Soviet political lexicon. At this time there emerged an official Soviet hierarchy of peoples, topped by the Russians, "the first among equals," followed next by the Ukrainians and Belorussians, and then by the other titular nations (ones that were the majority in their own union-level republic of the USSR). At the bottom of the hierarchy were the remaining ethnic groups. ${ }^{23}$

Another development of the war years was an alteration of the regime's attitude toward religion: in order to mobilize the population for the struggle 
against an external enemy, the Soviet leadership compromised on its atheistic ideological principles. Despite a general distrust of the clergy, who were on the whole loyal to the regime during the war, the authorities decided to demonstrate tolerance regarding religion to allow their subjects to resort to ethno-religious symbols and rhetoric in order to foster Soviet patriotism. ${ }^{24} \mathrm{In}$ the Jewish context, in the spring of 1942, in an interview with the Hebrewlanguage newspaper in Palestine Haiaretz, Itsik Fefer not only mentioned the Prophet Isaiah but called him a poet and a genius. In April 1944, the third rally of representatives of the Jewish people organized by the JAC inserted into a letter of greeting to Stalin the following quote in Hebrew, together with its Russian translation, taken from "ancient Jewish agada" in order to emphasize Jewish military tradition: "The Torah descended from Heaven and it had a sword in it." ${ }^{25}$

A synthesis of ethnocentrism and etatism formed the basis for Soviet patriotic propaganda in the years 1941-1942. ${ }^{26}$ Nevertheless, as David Brandenberger noted, "growing Russo-centrism during the first years of the war should be considered more of a tendency than an articulate central line." ${ }^{27}$ In such frameworks, despite their general control over them, the Soviet creative intelligentsia retained some flexibility of action in regard to interpretation of historical events. ${ }^{28}$ Sometimes, an ethnic intelligentsia initiated steps in this area. Such initiative was demonstrated by members of the Ukrainian intelligentsia who were close to Khrushchev, the First Secretary of the Communist Party in Ukraine at that time, when they suggested the introduction of a military decoration named after Bohdan Khmelnytskyi. This step was approved by Moscow. ${ }^{29}$ At Eynikayt, Epshteyn and Fefer, who were close to the Soviet authorities, established maximum boundaries for what was permitted in regard to referring to Jewish heroism. In other words, it was those people who had considerable experience in Soviet ideological activity who introduced a degree of flexibility that was compatible with the policy set from above.

In addition to general problems related to ethnic themes, there were aspects of life at this time that affected Jews specifically. A major one was the increasing antisemitism (partly "inspired" by Nazi propaganda) among part of the Soviet bureaucracy and among the Soviet population. The Soviet authorities had to decide how to react to this antisemitism, on the one hand, and how Soviet policy toward its own Jews might affect the attitude of the influential Jewish lobby in America and Great Britain toward the USSR. ${ }^{30}$ 
A noticeable increase in Russo-centric attitudes among the mid-level Soviet bureaucracy affected all non-Russian ethnic groups. This new approach, formed between the summer of 1943 and March 1944, stressed the uniqueness of the development of the Russian people and culture, as well as the positive (heroic) aspects of the Russian past and present, while condemning the nationalism of ethnic minorities unless they recognized the positive role of Russia/the USSR in their fate. ${ }^{31}$ Along with the further strengthening of the Russians' position, epitomized by the famous toast Stalin gave on May 24, 1945 to "the great Russian people," the Soviet bureaucracy returned to an emphasis on the principle of class struggle, including the Bolshevik thesis of the existence within each nation two opposing nations. (Stalin had already referred to the Soviet-German War as a class war). ${ }^{32}$

The authorities' advocacy of Russian nationalism was sometimes, paradoxically, accompanied by criticism of "great power" Russian nationalistic errors. This was especially the case when it was useful for government officials, as a rule in the speeches of Party apparatchiks that were closed to the public. ${ }^{33}$ A clear example of such criticism was the negative reaction of Party functionaries to the remarks of the historian Aleksei Iakovlev, a corresponding member of the Academy of Sciences of the USSR, at a meeting of the People's Commissariat (Ministry) of Education in January 1944. He had said: "We very much respect the nationalities that have entered our Union, we relate to them with love. But it was the Russian people who made Russian history.... We, Russians, want histories of the Russian people, histories of Russian institutions, in Russian conditions." ${ }^{4}$

However, despite occasional criticism, such neo-nationalistic ideas were also, apparently, popular among many Party functionaries in regard to their contemporary situation. The spring of 1943 witnessed the further advancement of Russians, Ukrainians, and Belorussians to socially significant positions. ${ }^{35}$

Within the framework of the existing ethnic hierarchy (with the Russians, of course, being the "elder brothers"), the hardening of the attitude toward the "middle brothers" (the non-Russian titular nations-for example, in the campaign against Ukrainian film director Aleksandr Dovzhenko at the beginning of $1944^{36}$ ) had a serious impact on what was permitted to the "younger brother" nations, as well as the Jews. However, in contrast to the Ukrainians, Kazakhs, Bashkirs, and Tatars, there was no question of Jewish rivalry with Russians in terms of the territorial expansion of the Russian 
Empire and hence the evaluation of the various ethnic heroes who had fought against Russians. For this reason, the tightening of general ideological control in 1944-1945 mainly affected the Jews in regard to the topic of Jewish heroism and its sources in the present rather than in the past.

\section{Soviet Policy and the Theme of Jewish Heroism}

According to data from the JAC, of 4,463 articles sent abroad in 1942-1943, 34.3 percent were devoted to Jews in combat and another 8 percent to Jews fighting with the partisans, which was more than the those about Nazi atrocities committed against the Jews (23.9 percent). ${ }^{37}$ Evidently, a similar situation existed in regard to material published in Eynikayt: the degree of attention to the topic of Jews engaged in combat that were sent abroad was the same as that in material published in the USSR. The main propagandistic methods in both foreign-published and domestic materials were also similar.

The aim of the Jewish intelligentsia to show Jewish heroism involved not only transplanting to the Jewish field propaganda devices that were generally employed during the war years, but also including a specific apologetics for Jewish courage and heroism. ${ }^{38}$ To a certain extent, the discussion of such issues was facilitated by the fact that the authorities allowed the establishment of frameworks for the collection of this type of information. At the first plenum of the JAC in May 1942, the decision was made to establish, along with a committee to collect materials about Nazi atrocities, a commission to collect material about Jews at war-in other words, about Jewish heroism. ${ }^{39}$ At the same time, supervision on the part of Party organs and censorship within the official frameworks did not allow the intelligentsia to express their concerns in print about the negative approach in the USSR in regard to Jews, and also limited opportunities for pride in the valorous behavior of Jews as representatives of their specific ethnic group.

Consequently, the Jewish intelligentsia, who considered it their duty to respond to these issues that were so sensitive for Jews, sometimes tried to use "code words" that were understandable to people familiar with Jewish culture, though they were not always expressed in an unambiguous manner. One of the most sensitive issues was that of inter-ethnic relations.

In the typical ethnic stereotype current among broad segments of the non-Jewish population in the USSR, the Jews were seen as merchants, not warriors. The accusation that Jews were draft-dodgers, which had been heard 
in the prewar period, became much more widespread during the war, and not only among the masses but also among parts of the high-ranking Soviet intelligentsia. ${ }^{40}$ This naturally aroused Jewish concern. However, the Soviet ban on mentioning inter-ethnic conflict, which had been in effect since the mid-1930s, became stricter during the war. In harmony with a required idealized picture of the situation in the country, the head of the Sovinformburo, Secretary of the Central Committee of the Communist Party Aleksandr Shcherbakov, stated that only positive information should be conveyed about the Soviet Union: "Why should we reveal to those abroad that we have traitors, that they are killing Jews, Russians, and Ukrainians. It is not appropriate for us to send those kinds of articles abroad." (The occasion for these remarks was an article sent abroad by the JAC about the murder of Jews by a Belorussian Nazi-collaborator. ${ }^{41}$ ) The trend toward a uniformly positive presentation of reality (in Il'ia Ehrenburg's pungent phrase, "in the style of [triumphant] salutes"42) became particularly pronounced in 1944.

Under these conditions, it was not possible to level direct accusations of antisemitism, including denying that Jews were not fighting at the front. At the second plenum of the JAC in February 1943, Ehrenburg reacted to the widespread view of the lack of Jewish participation in combat by proposing the issuing of a special publication devoted to the topic of Jews in the Red Army. However, when references to this antisemitic canard were printed in Eynikayt, objections were raised by the bureaucrats in charge of supervising the JAC; the supervisors expressed the view that too much attention was being paid to Jewish heroism. The critics of the "exaggeration" of Jewish heroism included Jews who were working in the general Communist propaganda apparatus, who were extremely sensitive to the current Party line. One of these was Bedrich Geminder (known in the Party as Fridrich), Director of the Press Department of the executive committee of the Communist International, a former Zionist and political emigrant from Czechoslovakia who lived in the USSR from 1938, who referred to this view among the Jewish intelligentsia as "inadmissible conceit and arrogance." ${ }^{43}$

Subsequently, at the third JAC plenum, in April 1944, in response to the new winds from the Soviet leadership, Epshteyn referred to antisemitism only indirectly (as the "revival of the remnants of the somber past, which have not yet been uprooted") and simultaneously criticized the "whiners" among the Jews as bearers of "unhealthy, narrow nationalistic attitudes." ${ }^{4}$ This was a return to the tactic of "fighting on two fronts," which was common in the 1920s 
and 1930s. It involved condemning nationalists among one's own people in order to avoid being tagged as a "nationalist" oneself.

In view of the way that nationalism was then being targeted, in May 1944 Ehrenburg responded as follows in a private letter to a Jewish woman who had complained about the newspapers' intentional disregard of the heroism of Jews and their failure to indicate the ethnic origin of Jewish heroes: "You must have developed this view because you have fallen in with very backward people who are lacking in culture." ${ }^{45}$

However, there was a way that Jews could criticize antisemitism in the USSR—by criticizing Nazi antisemitism. Thus, remarks condemning German antisemitism, which were quite common in JAC's Eynikayt, served as an unimpeachable journalistic way by which antisemitism could be broadly and seriously criticized without the risk of being branded as a nationalist. In this vein, in 1944, Itsik Fefer dared to hint that there were some Soviet citizens who, like the Nazis, were denying Jewish heroism: "The Jews are cowardsshout the fascists and their hangers on, their choirboys, and those who run after them" (or, in the juicy, untranslatable original Yiddish: "nokhtantser, nokhzinger, un nokhloyfer"). ${ }^{46}$ The following citation from A. Shefer ${ }^{47}$ can be seen as a logical response of Jews to all antisemitic (not only German) denigrations of Jews: “... [W] ay back in hoary antiquity, when the ancestors of today's German fascists wandered in animal skins through the wild forests of Europe, the Jewish people was already one of the bearers of world civilization. Already then it had a great culture and its banners reflected the glory of outstanding military battles." ${ }^{48}$ Shefer's remarks were not published as written. However, even in the much milder version that was published in September 1942, ${ }^{49}$ one could detect the desire of the Soviet Yiddish intelligentsia to defend Jewish dignity. This perception of a commonality between the Nazis and Soviet antisemites was in the minds of Soviet Jews also during the early postwar period. ${ }^{50}$

During the war itself, Eynikayt devoted much attention to the topic of the revolts in the ghettos of Warsaw, Białystok, and other places, and the participation of Jews in the partisan movement, in order to emphasize courage as a Jewish ethnic characteristic. ${ }^{51}$ Ehrenburg formulated this idea in general terms in an article devoted to the anniversary of the Warsaw ghetto uprising: "They salvaged nothing except honor-their own and that of their people." ${ }^{2}$ Other Soviet Jewish writers attempted to show "both themselves and the whole world" that we are "as good as others" (literally "no worse than oth- 
ers") $)^{53}$ and that Jewish fighters "do not give cause either to their parents or to the Jewish people to be ashamed of them." ${ }^{4}$

From the very first years of the war, Soviet authorities were very wary about the glorification of Jewish heroism itself, regardless of the general Soviet patriotic context. Thus, in May 1942, when preparations were being made for the second rally of representatives of the Jewish people, a phrase was removed from the text of Aron Kushnirov, the Yiddish poet who was in active service at the time. Kushnirov mentioned that he "experienced the feeling of national pride for the respect that [his friend battalion commissar Leibovich] had won for himself by his daring and bravery in battle." ${ }^{55}$ In the summer of the same year, the censor likewise removed from the journal Inostrannaia literatura (Foreign literature) the German-language article "The Attempt to Destroy the Jewish People," written by Klara Blum. She had wanted to include the idea of a particular Jewish heroism that was, apparently, common among Jews at that time:

Jews, together with Russians, Tatars, and Armenians, who are defending their Soviet homeland, in this just war alongside their brave countrymen, are playing not an equal but a particularly outstanding role. The proportion of Jews serving in the Red Army who are engaging in heroic acts ... significantly exceeds the proportion of Jews in the total population of the USSR. ${ }^{56}$

In order to avoid being accused of overemphasizing Jewish heroism during the course of the war, the JAC and its newspaper provided information about Jews awarded commendation for heroism in absolute numbers rather than in terms of proportional indicators. The latter would have made clear the disproportionately heroic role of Jews. ${ }^{57}$ Only half a year after Eynikayt published absolute figures about the ethnic background of Soviet heroes did Epshteyn (on November 8, 1944) write in the same newspaper that, while the Jews held seventh place in the USSR in terms of population, they were fourth in terms of military honors. ${ }^{58}$ Eynikayt paid particular attention to awards given to Jews of the highest honor, that of Hero of the Soviet Union, and also awards to officers and generals of the newly introduced Soviet battle commendations named after top Russian military figures of the past like Suvorov, Kutuzov, and Ushakov. ${ }^{59}$ This information was intended to make clear that patriotism and military prowess were no less characteristic of the 
Jews than their Russian counterparts. Toward the end of the war, Solomon Mikhoels touted the twice-honored Hero of the Soviet Union Colonel David Dragunskii as the most outstanding Jewish warrior in the Red Army ${ }^{60}$

Despite the similarity of its approach to that of Soviet patriotic propaganda, the Jewish treatment of heroism had certain unique features. For example, the latter lacked the kind of "mobilization" rhetoric addressed to Russians and Ukrainians that encouraged them to fight to liberate their native territories. In contrast, for Jews during the war years, the slogan "undzer land" ("our land") meant the USSR. However, the phrase "undzer folk" ("our people") was ambiguous, as it could refer either to the Jewish people or the Soviet people.

From its inception, Eynikayt stressed that Jews were fighting both for the whole Soviet homeland and for themselves, in a war of revenge for what the Nazis had been doing to their people-as David Bergelson put it, "Far zayn foterland un zany yidishn folk." ${ }^{11}$ During the initial period the newspaper sometimes stressed the idea of a specific "Jewish war" even beyond this context. In an article of June 28, 1942, Peretz Markish noted that "a depressingly terrible picture of innocent Jewish bloodshed stands before the eyes of every Jewish Red Army man; he cannot take his eyes off it; it demands: revenge!"62 However, even in such cases emphasis was placed on the joint heroic efforts of all Soviet peoples in the fight against Nazism.

However, it should be noted that, particularly during the late stages of the war, the idea of a special war of the Jews against the Nazis contradicted the views of contemporary Soviet bureaucrats regarding patriotism. In order to subordinate the idea of a particular Jewish war into the framework approved by the authorities, at the third rally of representatives of Soviet Jewry in April 1944, Epshteyn stated that the stimulus for the Jewish fighter was not the idea of "an eye for an eye, a tooth for a tooth" (i.e. revenge only for what had been done to the Jews), but the desire to take revenge for all Soviet civilian victims. ${ }^{63}$

\section{The Jewish Heroic Tradition}

As with any ethnic nationalism during the war, Soviet Jewish nationalism required its own variant of a mythologized, centuries-long heroic tradition that could be linked with the contemporary situation. The need to oppose antisemitism and to reject the view that Jews were incapable of engaging in 
combat added motivation to this search for historical continuity. In a 1942 article titled "Undzer shtolts" ("Our pride") Shakhno Epshteyn wrote that "the Hitlers of various times shouted that the Jewish people are ... cowards," although in the course of world history, by virtue of their heroism, Jews have shown that this is "an unfounded libel." ${ }^{4}$ This reinforced the need to create their conception of the continuity of Jewish heroism and military valor, and stressed specific Jewish national components.

Two articles in Eynikayt by A. Shefer under the general title " $D i$ shlakhtn traditsye funem yidishn folk" ("The military traditions of the Jewish people"), about military heroics by Jews in ancient times, the Middle Ages, and in modern times were completely devoted to this aim. ${ }^{65}$ Shefer's basic point was that throughout Jewish history, "heroism and courage were typical characteristics" of the Jews. His argument about a heroic tradition recalled the philosophy of Diaspora nationalism that stressed the continuity of Jewish history. Shefer saw this heroic tradition as beginning with Deborah the judge, whom he referred to as the "Joan of Arc of the Jewish people," and continuing on to include Jews who fought in American and European wars of independence in the eighteenth and nineteenth centuries. His heroes included Samson, the Maccabees, Bar Kochba, and other ancient warriors, some of whom had become symbols of Jewish nationalism and were popularized in Zionist discourse. Among Shefer's modern heroes were Jews who fought in European armies against Napoleon, whom-due to his invasion of Russiathe discourse of Soviet propaganda viewed as a precursor of Hitler.

In an effort to demonstrate the East European roots of Jewish heroism and its continuity, Yiddish critics and literary scholars Yehezkel Dobrushin and Nokhem Oyslender analyzed the image of the Jewish fighter in the work of Sholem Aleichem. Among the works by this leading Yiddish writer that recall the heroism of Jewish soldiers, these literary critics referred to a series of stories from 1915 that were collected under the title "Mayses fun toyzent eyn nakht" (Stories of a Thousand and One Nights). The young hero, Shmuel Moyshe, volunteers for combat during the First World War. He was motivated by Russian patriotism, which had been quite negatively evaluated in the early Soviet period but was highly appreciated in the new wartime conditions. In the literary work the Jewish hero is awarded three medals, including the St. George Cross, for valor. Dobrushin and Oyslender stressed that all the stories are permeated with hatred for the German enemy, claiming that Sholem Aleichem's protagonist is a "clearly expressed positive model," who, 
armed with that hatred, proceeds from one battle to the next. ${ }^{66}$ Oyslender and Dobrushin, however, did not mention that Sholem Aleichem indicates that Shmuel Moyshe had volunteered for military service not only for patriotic reasons but also out of the desire to show that Jewish public activity was not restricted to selling fish. ${ }^{67}$ These stereotypes might well have reminded Oyslender and Dobrushin of anti-Jewish prejudices in their own time.

Various Jewish heroes of the past, both historical and literary, were viewed as leading to the figure of the Yiddish poet Osher Shvartsman, who fought in World War I and was killed in combat in the ranks of the Red Army in 1919. This image was also important, since it related to heroism in the Soviet period itself. (According to Meir Wiener, Shvartsman was "the creator of the lofty tradition of Soviet patriotism." ${ }^{68}$ )

During the war, the term "Shvartsman-traditsie," i.e. the heroic tradition exemplified by Shvartsman, was coined to connect Jewish heroism of the past to that of the present. In December 1944, to commemorate the twenty-fifth anniversary of Shvartsman's death, a World War I-era photograph of him was first published, showing him in the uniform of the dragoons, with two St. George Crosses on his chest. ${ }^{69}$ Shvartsman became a model for members of the Soviet Yiddish intelligentsia, especially for those who fought on the front lines in the Second World War (prose-writer Shmuel Godiner, Kushnirov, poet and short-story writer Shmuel Rosin, and others). Rosin wrote: "Like you, Osher, I must fight with verse and sword."70 Another Yiddish poet, Motl Golbshteyn, stressed his identification with his idol: "And if I have to fall from a bullet that landed in my heart, on a deserted road, in a green field, then [may it be] like you, my dear Osher Shvartsman, as a warrior, a poet, and a hero." ${ }^{71}$

Depending on the different cultural milieus in which they were raised, Jews hailed different Jewish heroes. Itsik Fefer, a former prominent member of a proletarian group in Soviet Yiddish literature, whose background included a rich Yiddish cultural environment and who during the war clearly emphasized Jewish themes and, sometimes, even clearly went beyond the boundaries of the officially sanctioned ethnic discourse, focusing on Jewish heroes who were a part of that traditional Jewish orientation. In various war writings that were devoted to Jewish heroism, including his famous poem "Ikh bin a yid" ("I am a Jew"), Fefer referred to Bar Kochba and Rabbi Akiva, the Maccabees, and to Jews in Madrid who were burned in the fires of the Inquisition. Although he did not explicitly use the term "kiddush haShem," one does encounter in Fefer's texts the idea of martyrdom for Jewish religious 
values: "Our ancestors often gave their lives for their people, for their ideals. They fell not as slaves but as heroes." Furthermore, Fefer does use the Yiddish term "kdoyshim," meaning "holy martyrs," in referring to the mass murders of Jews. Jewish readers could easily recognize this term as a sign that the victims were killed not simply as Soviet citizens, as official Soviet propaganda proposed, but for being Jews. In addition, when Fefer contrasts activity in the humanities and in military affairs, he cites examples not only from Russian history (for example, Tchaikovsky vs. Suvorov) but also from Jewish history (Yehuda Halevi and Bar Kochba). ${ }^{72}$

Allusions to Jewish historical symbols were addressed not only to the Yiddish intelligentsia. For example, when representatives of the Jewish religious community of Kuibyshev sent a telegram to Stalin (in January 1943) about their contribution of ten thousand rubles to the Soviet war effort, they proposed creating a tank column named after Bar Kochba, "the immortal hero of the struggle for the liberation of our people." ${ }^{33}$

However, these images, including Bar Kochba and the Maccabees, were basically alien to those Jews, like Ehrenburg, who had grown up outside a Jewish environment. For them, Jewish heroes of the distant past were limited to those from the Bible, like King David. At the same time, such Biblical heroes were also used in the general (i.e. non-Jewish, Soviet) propaganda, including by heads of the Russian Orthodox Church. ${ }^{74}$

Of course, emphasis on exclusively ethnic heroes was not solely a Jewish phenomenon. For example, the Ukrainian intelligentsia focused on their historical anti-German tradition, preferring to recall Danila Galitskii (of Galich), a thirteenth-century prince of Galicia-Volyn, rather than heroes of Kievan Rus', whom they would have to share with the Russians. ${ }^{75}$

During the last period of the war, the expansion of Russo-centric attitudes among the Soviet bureaucracy and of control over ethnic topics negatively affected the attempt of the Jewish intelligentsia to create a clearly manifest, uninterrupted centuries-long historical continuity, although the drawing of analogies with specific Jewish heroes of the past was, as before, allowed.

\section{Soviet Jewish Heroes}

Eynikayt tried to link the Jewish fighting tradition of the past with the heroism of Soviet Jews. In the newspaper, Fefer compared a contemporary Jew, Shloyme Gorelik, with a historical prototype: "Thus there fell in battle a Soviet 
Bar Kochba." ${ }^{76}$ An article by D. Leitses, sent abroad under the title "A Soviet Jewish Samson," used the image of Samson to describe the death at Stalingrad of Eli Shnaider, who used his last grenade to blow himself up along with the German soldiers who surrounded him. ${ }^{77}$

Most of Eynikayt's materials hailing Jewish heroism related to examples of individual Jewish soldiers, officers, partisans, and ghetto fighters. In order to stress the connection of the hero with his Jewishness, the newspaper used the hero's original Jewish name rather than his Russian one (Yankev instead of Iakov, Chaim instead of Efim, Shloyme instead of Solomon, etc.). Often the connection of the hero to his Jewish origin was indicated by familial continuity: the hero might refer to ancestors who were soldiers under Tsar Nicholas I and about whose heroism he had heard from family members. ${ }^{78}$ In other cases, the connection was a spiritual rather than a physical one. In an article about two different persons with the same family name, Shoykhet-a simple religious Jew and a young Soviet lieutenant-David Bergelson, in his usual manner, encouraged the reader to draw his own conclusions, in this case about Jewish continuity: "They are very different, these Jews-the pre-revolutionary Moyshe-Leyb Shoykhet and Lieutenant Shoykhet. They did not know each other, but there was something profound that Lieutenant Shoykhet inherited from the Jew Moyshe-Leyb Shoykhet."79

Shmuel Persov's article about General Iakov Kreizer, who was a member of the Jewish Anti-fascist Committee, conveyed the General's Jewish origin by referring to a German leaflet that called upon Russian soldiers to avoid fighting under the leadership of the Jew Yankel Kreizer. Kreizer kept a copy of the leaflet in the pocket of his uniform. He reported that his parents had called him Yankel and said that he was proud of this name. However, when the article was published, its original title "The Jew Yankel Kreizer" was replaced by the more ethnically neutral "Hero of the Soviet Union Yankev Kreizer." ${ }^{80}$ Eynikayt also reported that in one of the questionnaires that he filled out during the war years, when he already had a command position in army artillery, General Izrail Beskin listed Yiddish as his native language. ${ }^{81}$

Most often, the link of the Jewish hero to a Jewish environment was conveyed by information about his family origin and childhood. On a number of occasions, an article presented a hero's biography based on a long-lasting pre-war propagandistic model that emphasized the contrast between the poverty-stricken and humiliating life of Russian Jews before the Revolution and the vast opportunities provided to them in the Soviet period. ${ }^{82}$ 
This emphasized the theme of Soviet patriotism, which had featured more prominently toward the end of the war. Almost all of Persov's articles were constructed in that way. An article about General Mikhail Cherniavskii illustrates the way he connected the present to the past: "In Kiev his father, Leyb Cherniavskii, crushed [kvetsht in Yiddish] raisins to make raisin wine for kidesh and havdole. His son exchanged his father's profession for another one: with his tanks he crushed [kvetsht] the German fascist hordes." ${ }^{83}$

Many articles highlighted the skill and intelligence displayed by Jews in combat and related how proud their non-Jewish colleagues were of them. Praise for talented and courageous Jews was often linked to their characteristics as members of the intelligentsia. Heroes were portrayed as interested in poetry and music and possessing creative talents regardless of whether they were professional soldiers or professional linguists. Thus, Eynikayt readers learned that Isaak Kabo, the well-known commander of a submarine in the Baltic Fleet, ${ }^{84}$ had played the violin from childhood and intended to become an architect. However, he refocused his energies and entered a military academy. Leyb Kvitko described this combination of military valor and love for the violin, which in the Russian Jewish tradition came to be considered a "Jewish" instrument, is this way: "S'iz Itskhok Kabo der fidl-shpiler, der fidl shpiler-torpeder-tsiler, undzer shtolts un khies" "“That is Itshok Kabo, a violinist who knows how to aim torpedoes, our pride and our vital strength"). ${ }^{85}$

Another means of demonstrating Jewish heroism was by providing examples of how Jews fought courageously in all branches of the Soviet armed forces, on land and sea, in the air and underwater, with the partisans and in the ghetto. ${ }^{86}$ In fact, Jews were even pointed out in places one would hardly expect them, in forces that were quite unusual for World War II. A striking example of this was the account of the exploits of Khaim (Efim) Popov, who was a commander of a Kuban Cossack cavalry division, known in the Jewish milieu for its hostility to and condescension toward Jews. ${ }^{87}$

More often, though, the presence of Jews was noted in quite up-to-date forces. This corresponded to the expectations of many of Eynikayt's readers to see the contemporary Jew as fully modern and successful in social terms, especially in contrast to Jews of previous times. Fefer wrote about Israel Fisanovich, a member of the Jewish Anti-Fascist Committee and a famous submarine commander in the Northern Fleet, as follows: "His grandfather, a melamed from Konstantingrad, might well have said, 'underwater my Isrolik is like the prophet Jonah in the belly of the fish."'88 
In writing about Fisanovich, Fefer included another important innovation in the depiction of the Jewish hero. Before the war the image of a hero had to have the physical features of a "muscular Soviet Jew." During the war years this characteristic was no longer obligatory. The main criterion was personal courage - the idea (stressed in the mainstream Soviet press) was that in such a terrible war anyone, including members of the intelligentsia, a woman, or a child, might become a hero. This idea was confirmed by references to official decorations for bravery that were awarded to such people. An illustration of this idea is the way Fefer describes Fisanovich's physical appearance before continuing with the signs of his military prowess: "Short, frail, with an elongated face, he stands before you in a dark blue uniform, with gold braid on his sleeves, and two Orders of the Red Banner, an Order of Lenin, and a Gold Star on his chest." A similar description was penned about a heroic airman by the young Yiddish prose-writer Hershl Polyanker: "Six combat medals adorn the chest of a short Jewish lad with two bright, almost childlike eyes."

It was demonstrated that not only could Jewish men be heroes, but also Jewish women. Often the Jewish heroine was a medical instructor or a physician, almost always serving in the armed forces as a volunteer. In regard to one Jewish heroine, the prose writer Faivel Sito wrote that before the war, Ida Epshteyn focused on her undramatic medical specialization as an oculist whose main tool was a rubber pipette. However, when war came, the reader was told how this unassuming woman volunteered for front-line duty and, exchanging her rubber pipette for a scalpel, became a surgeon in a front-line hospital. ${ }^{90}$ The heroine's link to the Jewish people was often indicated by references to relatives who had been murdered by the fascists. This was especially the case in regard to Jewish women fighting in the ranks of the partisans; for these heroines the desire to take revenge had become their life goal and, hence, the motivation for their heroism..$^{91}$

A similar approach was taken in the depiction of heroism on the part of Jewish children in the partisan ranks. Among the heroes in the ranks of the partisans were Simka, a 10-year-old girl who succeeded in smuggling one hundred Jews out of the Minsk ghetto, and 13-year-old Yankel Bobitskii, the member of a partisan unit that blew up trains. This lad was awarded three military decorations. ${ }^{92}$

As in the non-Jewish Soviet press, examples of children's heroism were exploited to encourage self-sacrifice on the part of adults. However, the Jewish variant of this theme also reflected the indestructible desire that Eynikayt 
writers saw in such children (as well as in Jewish adults who had survived in Nazi-occupied territories) to remain alive and to take revenge on the Nazis for their murdered families and the destruction of their shtetl homes. ${ }^{93}$

\section{Conclusion}

Many articles in Eynikayt, like the articles sent abroad by the JAC, were permeated with the theme of Jewish heroism and stressed the specific ethnicity of Soviet heroes of Jewish origin. The authors of these articles evidently believed that such an approached corresponded to the wishes of Soviet Jews.

Several factors affected the way that Jewish heroism was portrayed, especially during the two last years of the war. These included: the increase of Russo-centrism and antisemitism among Soviet bureaucrats, their patronizing attitude toward the Jews as one of the "little brothers" of the Russian people, and officials' fear that Nazi propaganda regarding alleged Soviet special treatment of the Jews would undermine Soviet patriotism. Although references in Eynikayt to the Jewish heroes of the past were still permissible, the depiction of an uninterrupted tradition of Jewish heroism became less pronounced as limitations on ethnic distinctions were imposed in regard to history as well.

In the post-war years, the topic of Jews in the war was viewed by the authorities as "out of date" and thus basically disappeared from the pages of Eynikayt (with the exception of publications devoted to particular events, like Victory Day [May 9] or the fifth anniversary of the revolt in the Warsaw Ghetto). However, the publication between 1946 and 1948 of books about the heroism of Jews in the army, in ghetto uprisings, and among the partisans testified to the fact that the need among the Jewish intelligentsia to extol Jewish heroism remained strong. ${ }^{94}$ Even Fefer, much of whose writing during the first years after the war was in an aggressively Soviet style, saw in the deeds of those Jews who revolted in the Warsaw Ghetto a guarantee of the future proud existence of the Jews. He wrote: "The events that took place five years ago in Warsaw still await the artist who will commemorate them. The farther we get from those historic days the more pain we feel and, also, the more pride in our brothers who, once again, have shown the world that our people are still alive and will continue to live." ${ }^{95}$ However, before being published in Eynikayt, these words conveying the feeling of many members of the Yiddish intelligentsia were censored to reduce their Jewish national content. 
The theme of Jewish heroism and the idea of the unity of the Jewish people could no longer be used to oppose to Nazi antisemitic propaganda and to mobilize Jews in the USSR and abroad to support the fight of the Soviet Union against its enemy. The Soviet authorities already had other aims.

\section{Notes}

1 I thank my friend and colleague Dr. Yisrael Elliot Cohen for his help in preparing this article.

2 “Idn-heldn fun Sovetn-Farband," Eynikayt, June 25, 1943.

3 Zvi Y. Gitelman, "Internationalism, Patriotism and Disillusion," in The Holocaust in the Soviet Union, Symposium presentations (Washington, D.C.: Center for Advanced Holocaust Studies, United States Holocaust Memorial Museum, 2005), 95-125; Mordechai Altshuler, "Hamifgash lohamim yehudim batsava haadom leshoah," Dapim leheker hashoah 23 (2009): 9-27.

4 On the activity of Anti-Fascist Committees, see N. K. Petrova, Antifashistskie komitety $v$ SSSR, 1941-1945 (Moscow: Institut Rossiiskoi istorii, 1999). On the JAC, see Shimon Redlich, War, Holocaust and Stalinism: A Documented Study of the Jewish Anti-Fascist Committee in the USSR (Luxembourg: Harwood Academic Publishers, 1995); Gennadii Kostyrchenko, Stalin protiv "kosmopolitov": Vlast' i evreiskaia intelligentsiia v SSSR (Moscow: Rosspen, 2009); Ilya Altman, "The History and Fate of The Black and The Unknown Black Book," in The Unknown Black Book: The Holocaust in the German-Occupied Soviet Territories, ed. Joshua Rubenstein and Ilya Altman (Bloomington and Indianapolis: Indiana University Press, 2008), xix-xxxix.

5 On Eynikayt, see Avraham Grinbaum, “Todaa leumit yehudit bepublitsistika hasovietit betkufat ha'eynikayt', Dapim leheker tkufat hashoah 1 (1979): 213-21; Dov Ber Kerler, “The Soviet Yiddish Press: Eynikayt During the War, 1942-1945," in Why Didn't the Press Shout? American and International Journalism during the Holocaust, ed. Robert Moses Shapiro (Jersey City, NJ: Yeshiva University Press, 2003), 221-49.

6 "Spravka o deiatel'nosti evreiskogo antifashistskogo komiteta v SSSR za period s 1 iunia 1945 goda do 27 iunia 1946 goda," Gosudarstvennyi arkhiv Rossiiskoi Federatsii (GARF) f. 8114, op. 1, d. 919, 1. 69-70. The documents from the JAC collection that are cited were examined were copies at the Yad Vashem Archives in Jerusalem.

7 GARF f. 8114, op. 1, d. 1062, 1. 8-12.

8 "Plenum Evreiskogo antifashistskogo komiteta: Otchet o rabote evreiskogo antifashistskogo komiteta" (GARF f. 8114, op. 1, d. 1064, 1. 70). It is difficult to assess the influence of Eynikayt on Soviet Jews, either in the rear or at the front since the extent of its distribution in terms of readership at that time is not clear. The responses of Jews at the front to material in Eynikayt that were cited by the JAC ("Eynikayt na fronte" [GARF f. 8114, op. 1, d. 919, 1. 72-74]; "Otchet o rabote evreiskogo antifashistskogo komiteta" [GARF f. 8114, op. 1, d. 1064, 1. 68]) reflect other matters, i.e., the need of members of the Committee to justify the significance of the newspaper rather than the actual degree of its influence. It is clear that the thousands of its essays' subjects and their relatives and friends, both at the front and in the rear, knew about such 
publications. In any case, the subject of the present article is those who wrote for the newspaper.

9 “A briv funem held fun Sovetn farband Khaim Diskin," Eynikayt, December 5, 1942, 2. On Chaim Diskin, see the article by Rakhmiel Fish, "Held fun ratn-farband Khaim Diskin," Eynikayt, August 25, 1942, 3, and the book by Moshe Khashtshevatski, Khaim Diskin: Der held fun sovetn-farband (Moscow: Der emes, 1943).

On Shakhne Epshteyn, see Gennady Estraikh, In Harness: Yiddish Writers' Romance with Communism (New York: Syracuse University Press, 2005), 71.

11 On Itsik Fefer, see Gennady Estraikh, "Itsik Fefer: A Yiddish Wunderkind of the Bolshevik Revolution," Shofar 20.3 (2002): 14-31.

12 It is those members of the Soviet creative intelligentsia, and not Party functionaries, who were the initiators of the Moscow renewal of the Yiddish newspaper in July 1941. They appealed for its reestablishment on the grounds that it would significantly contribute to the "mobilization" of Soviet Jews in the fight against Nazism (Redlich, War, Holocaust and Stalinism, 186). On general tendencies in Soviet Yiddish literature during the war and the first post-war years, see Ch. Shmeruk, "Yiddish Literature in the USSR," in The Jews in Soviet Russia since 1917, ed. Lionel Kochan (Oxford: Oxford University Press, 1978), 271-76.

13 Redlich, War, Holocaust and Stalinism, 287-89, 291.

14 On details of this campaign, see David Brandenberger and Kevin M. F. Platt, eds., Epic Revisionism: Russian History and Literature at Stalinist Propaganda (Madison: The University of Wisconsin Press, 2006).

15 On Soviet propaganda in regard to the Ukrainians, see Serhy Yekelchuk, "Stalinist Patriotism as Imperial Discourse: Reconciling the Ukrainian and Russian 'Heroic Pasts,' 1939-45," Kritika 3.1 (Winter 2002): 57-61.

16 Arkadii Zel'tser, Evrei sovetskoi provintsii: Vitebsk i mestechki 1917-1941 (Rosspen: Moscow, 2006), 180-81; The removal of Lekert's name was not connected to his affiliations with the Bund. The Communist fight against the historical role of the Bund, especially in Belorussia, was strong in the 1920s when he was recognized as a hero. Lekert's name continued to appear in Belorussia until 1937, when a middle-ranking functionary wrote a letter to the Party leadership pointing out the Bundist Lekert's shortcomings and, hence, the inappropriateness of naming places and institutions in Belorussia after him. Lekert's name was removed from Soviet geography in Crimea only in 1945, when there was a massive renaming of places, especially those with Tatar names (Ibid.; Nikolai F. Bugai, Deportatsiia narodov Kryma [Insan: Moscow, 2002], 125).

17 Jeffrey Veidlinger, The Moscow State Yiddish Theater: Jewish Culture on the Soviet Stage (Bloomington: Indiana University Press, 2000), 159-60.

18 On Zionist heroes, see Yael Zerubavel, Recovered Roots: Collective Memory and the Making of Israeli National Tradition (Chicago: University of Chicago Press, 1995).

19 Shmuel Halkin, Bar Kokhba (Moscow: Der emes, 1939), 100. For more details about the production of the Moscow GOSET, see Veidlinger, The Moscow State Yiddish Theater, 168-73. In March 1942 the Belorussian GOSET began working while under evacuation in Novosibirsk with a production of "Bar Kochba." 
20 Alfred Abraham Greenbaum, Jewish Scholarship and Scholarly Institutions in Soviet Russia 1918-1953 (Jerusalem: Centre for Research and Documentation of East European Jewry, 1978), 121-23.

21 I. Stalin, O Velikoi Otechestvennoi voine Sovetskogo Soiuza (Moscow: 1943), 67, 95.

22 On the influence of nationalist propaganda on the Russian population, see David Brandenberger, National Bolshevism: Stalinist Mass Culture and the Formation of Modern Russian National Identity, 1931-1956 (Cambridge, MA and London: Harvard University Press, 2002), 160-80. There was, apparently, a basis for the charge of increased nationalism against the ethnic intelligentsias of Ukraine and Kazakhstan. See. L. Gatagova, L. Kosheleva, L. Rogovaia, and J. Kadio, eds., TsK VKP(b) i natsionlal'nyi vopros, vol. 2: 1933-1945 (Moscow: Rosspen, 2009), 827, 858-59, 878-82.

23 Terry Martin, The Affirmative Action Empire: Nations and Nationalism in the Soviet Union, 1923-1939 (Ithaca and London: Cornell University Press), 451-61; Yekelchuk, "Stalinist Patriotism as Imperial Discourse," 61-63.

24 Aleksandr Livshin and Igor Orlov, eds., Sovetskaia propaganda $v$ gody Velikoi Otechestvennoi voiny (Moscow: Rosspen, 2007), 541-46; Mordechai Altshuler, Yehadut bemakhbesh hasovieti: Bein dat vezehut yehudit bevrit hamoatsot 1941-1964 (Jerusalem: Merkaz Zalman Shazar, 2007), 23-42.

25 Shmuel Valkovits, "Alilot hagvura shel hayehudim berusiya," Haaretz, May 24, 1942; Evreiskii narod $v$ bor'be protiv fashizma (Moscow: Ogiz, 1945), 4.

26 On Soviet patriotic propaganda during the war, see, for example, Jeffrey Brooks, Thank You Comrade Stalin: Soviet Public Culture from Revolution to Cold War (Princeton: Princeton University Press, 2000), 164-94.

27 David Brandenberger, National Bolshevism, 120.

28 For example, there is consideration of different attitudes toward the image of Ivan the Terrible on the part of Party functionaries, historians, and figures in the arts in the article by Kevin M. F. Platt and David Brandenberger, "Terribly Romantic, Terribly Progressive, or Terribly Tragic: Rehabilitating Ivan IV under I.V. Stalin," The Russian Review 58 (October 1999): 635-54.

29 Yekelchuk, "Stalinist Patriotism as Imperial Discourse," 68-71.

30 Il'ia Altman, Zhertvy nenavisti (Moscow: Fond Kovcheg, 2002), 388, 392-93, 399, 411-13; David Brandenberger, National Bolshevism, 117; Kostyrchenko, Stalin protiv "kosmopolitov," 94-107. The Germans kept track of the promotion of Jews in the Soviet military, their attainment of the rank of general, and Soviet press accounts of Jewish heroism in battle. Nazi propaganda presented such material as proof of Bolshevik favoritism regarding the Jews (GARF f. 8114, op. 1, d. 1942, 1. 197-98).

31 Irina Il'ina, "Novye dokumenty o soveshchanii istorikovv TsK VKP(b) (1944)," Voprosy istorii, no. 1, (1991): 188-205; Iurii Amiantov and Zoia Tikhonova, "Stenogramma soveshchaniia istorikov v 1944 g.," Voprosy istorii, nos. 2-7, 1996; Livshin and Orlov, eds., Sovetskaia propaganda, 494-535.

32 Pravda, November 7, 1944.

33 Irina Il'ina, “Novye dokumenty o soveshchanii istorikov v TsK VKP(b)," 202. Ibid. 

German fascists first began to appear on the historical scene, the Jewish people already had a glorious past rich in immortal military heroism" (A. Shefer, "Di shlakhtn traditsie funem yidishn folk," Eynikayt, September 5, 1942, 2).

Amir Weiner, Making Sense of War: The Second World War and the Fate of the Bolshevik Revolution (Princeton: Princeton University Press, 2001), 191-94.

51 A number of articles in Eynikayt by Ber Mark were devoted to the uprisings in some of the ghettos. See Eynikayt, May 15, 1943, 4; July 17, 1943, 2; June 1, 1944, 2.

Kostyrchenko, Stalin protiv “kosmopolitov," 97, 102; Il'ia Erenburg, Liudi, gody, zhizn', vol. 2 (Moscow: Tekst, 2005), 390.

Valerii Fomin, ed., Kino na voine: Dokumenty i svidetel'stva (Moscow: Materik, 2005), $382,391$. op. 1, d. 1063, 1. 52-54).

An example of such an apology for Jewish heroism is the article by Itsik Fefer, "Azoy shlogn zikh yidn," Eynikayt, October 5, 1944, 2.

"Plenum Evreiskogo antifashistskogo komiteta: Otchet o rabote Evreiskogo Antifashistskogo komiteta” (GARF f. 8114, op. 1, d. 1064, 1. 1).

Arkadii Zel'tser, Evrei sovetskoi provintsii, 210-11. Such views were expressed especially by Mikhail Sholokhov (Notes of Boris Frezinskii to the publication Il'ia Erenburg, Liudi, gody, zhizn', vol. 3 [Moscow: Tekst, 2005], 495). Erik van Ree examines such currents in Stalin's own outlook in his article "Heroes and Merchants: Stalin's Understanding of National Character," Kritika 8.1 (Winter 2007): 41-65. The view of "the inherent lack of capability" of certain peoples (Uzbeks, Georgians, Azeris, etc.), for military service was widespread in the army and, possibly, also among broad segments of the population (TsK VKP [b] i natsionlal'nyi vopros. vol. 2, 757, 762).

Antifashistskie komitety $v$ SSSR, 207.

Andrei Artizov and Oleg Naumov, eds., Vlast' i khudozhestvennaia intelligentsiia: Dokumenty 1917-1953 (Moscow: Mezhdunarodnyi Fond “Demokratiia," 1999), 529. 1943.

Evreiskii narod $v$ bor'be protiv fashizma, 71.

Il'ia Ehrenburg, Na tsokole istorii... Pis'ma 1931-1967 (Moscow: Agraf, 2004), 329.

Iitsik Fefer, "Felker-brider," Eynikayt, March 2, 1944, 3.

There are some indications that Itzik Fefer wrote using the pen name A. Shefer. See Avraham Grinbaum, "Todaa leumit yehudit bepublitsistika hasovietit betkufat ha'eynikayt,' 217, and GARF f. 8114, op. 1, d. 854, 218.

A. Shefer, "Vozrozhdenie voennykh traditsii evreiskogo naroda v Otechestvennoi voine" (GARF f. 8114, op. 1, d. 82, 1. 544).

Il'ia Erenburg, "Godovshchina vosstaniia v Varshavskom getto" (GARF f. 8114, op. 1, d. $88,1.18)$.

V. Fink, "Vstrecha s polkovnikom Dragunskim" (GARF f. 8114, op. 1, d. 160, 1. 291).

P. Lerner, "Shestero synovei" (GARF f. 8114, op. 1, d. 179, 1. 331). 
"Rech' evreiskogo sovetskogo poeta A. Kushnirova" (GARF f. 8114, op. 1, d. 1125, 1. 5). Livshin and Orlov, eds., Sovetskaia propaganda, 663.

"Yidn heldn fun sovetn-farband," Eynikayt, June 25, 1943, 7; Itsik Fefer, "Felkerbrider." According to data for October 5, 1942, Jews accounted for 2.8 percent of those honored for heroism, and for January 1, 1944-for 2.1 percent, while the 1939 Soviet census had indicated that Jews comprised 1.8 percent of the Soviet population (Evreiskii narod $v$ bor'be protiv fashizma, 67; L. Zinger, Dos banayte folk [Moscow: Ogiz, 1941], 35).

Shakhne Epshteyn, "Dos vidergeburt fun a folk," Eynikayt, November 8, 1944, 4; Fefer, "Felker-brider." This may have been a reaction to Stalin's remark, on November 6, 1944, at a meeting of the Moscow soviet, that "Soviet patriotism does not divide but, on the contrary, unifies all the nationalities and peoples of our country into a single fraternal family" (Pravda, November 7, 1944).

"Undzer heldn," Eynikayt, February 27, 1943, 8.

Sh. Persov, "A bagegenish mitn tsvey mol held fun sovetn-farband Dovid Dragunski," Eynikayt, December 1, 1945, 2. See also V. Fink, "Vstrecha s polkovnikom Dragunskim.

61 David Bergelson, "Der yunger sovetisher yid," Eynikayt, November 7, 1942, 6. On Bergelson's journalistic writing during the war, see David Shneer, "From Mourning to Vengeance: Bergelson's Holocaust Journalism (1941-1945)," in David Bergelson: From Modernism to Socialist Realism, ed. Joseph Sherman and Gennady Estraikh (London: Legenda, 2007), 248-67.

62 Peretz Markish, "Heroik un patriotizm fun yidishe roytarmeyer," Eynikayt, June 28, 1942, 3.

63 Evreiskii narod $v$ bor'be protiv fashizma, 60. Shakhne Epshteyn, “Undzer shtolts," Eynikayt, June 28, 1942, 2.

A. Shefer, "Di shlakhtn traditsie funem yidishn folk," Eynikayt, September 5, 1942, 2; January 7, 1943, 3.

Y. Dobrushin and N. Oyslender, "Der yidisher shlakhtman bai Sholem Aleykhemen," Eynikayt, February 10, 1944, 3.

67 Sholem Aleykhem, Ale verk fun Sholem Aleykhem (Vilna, Warsaw: Vilner farlag fun B. Kletskin, 1925), vol. 3, 216-17.

68 M. Notovich, "Mit biks in hant, mit vorem blut in hartsn" (GARF f. 8114, op. 1, d. 262, 1. 44).

69 Shakhne Epshteyn, "Osher Shvartsman, groyser dikhter, heldishe shlakhtman," Eynikayt, December 14, 1944, 3-4. M. Notovich, "Tray der Shvartsman-traditsye," Eynikayt, October 28, 1943, 4. The collection of Shvartsman's poems "Ale lider" was republished in Moscow in 1944.

70 M. Notovich, "Mit biks in hant, mit vorem blut in hartsn."

71 M. Golbshteyn, “Osher Shvartsman," Eynikayt, October 6, 1942, 3.

72 The short version of "Ikh bin a yid" was published in Eynikayt in December 27, 1942, 3. For the full version, see Chone Shmeruk, A shpigl oyfn a shteyn (Jerusalem: Magnes Press, 1964), 694-97. Itsik Fefer, "Nit tsurik in geto, nor faroys in shlakht," Eynikayt, August 15, 1942, 2; Itsik Fefer, "Azoy shlogt men yidn," Eynikayt, October 5, 1944, 2; 
Itsik Fefer, "Shloyme Gorelik, der held fun Sovetn Farband," Eynikayt, December 5, 1942, 2.

"Far a tanken kolone 'Bar Kokhba"' (GARF f. 8114, op. 1, d. 541, 1. 262). However, this was not permitted and so the tank column was named Soviet Birobidzhan (GARF 8114-1-910, 1. 41). which was published in Moscow in 1935, followed this pattern (see the article in this collection by Abram Kirzhnits, "Di tsarishe yerushe," 183-84). The same idea was central to the exhibition "Jews in the Tsarist Russia and in the USSR" that opened in the State Museum of Ethnography in Leningrad in March 1939 (Alexander Ivanov, “'Evrei v tsarskoi Rossii i v SSSR': Vystavka dostizhenii evreiskogo khoziaistvennogo i kul'turnogo stroitel'stva v strane sovetov," Novoe literaturnoe obozrenie 102 [2010]: 158-82).

Sh. Persov, "Yidn generaln fun tanken-militer," Eynikayt, June 22, 1944, 4.

Leyb Kvitko, "Isak Kabo der kapitan fun untervaser-shif," Eynikayt, March 15, 1943, 7.

Leyb Kvitko, "Kapitan Isak Kabo," Eynikayt, April 5, 1943, 3.

Peretz Markish, "Heroik un patriotizm fun yidishn roytarmeyer."

On Jews and their attitude to Cossacks see also Gennady Estraikh, "Jews as Cossacks: A Symbiosis in Literature and Life" in this volume.

Itsik Fefer, "Yisroel Fisanovich, der held fun Sovetn Farband," Eynikayt, June 28, $1942,3$.

Hershl Polyanker, "Der veg af varshe," Eynikayt, October 12, 1944, 3.

Faivel Sito, "Der heldisher doctor Ide Epshteyn," Eynikayt, March 9, 1944, 3.

V. Pomerantsev, "Evreiskie partizany" (GARF f. 8114, op. 1, d. 170, 1. 260).

Fefer, "Azoy shlogt men yidn"; GARF f. 8114, op. 1, d. 179, 1. 349.

Fefer, "Azoy shlogt men yidn"; Pomerantsev, "Evreiskie partizany."

См. Abraham Ben Yosef, "Bibliografiya shel sifrei yidish shenidpesu bevrit hamoatsot beshanim 1941-1948," Yad Vashem Studies 4 (1960): 143-60.

For a translation of Fefer's Yiddish article into Russian, see Itsik Fefer, "Ikh vdokhnovliala Sovetskaia armiia" (GARF f. 8114, op.1, d. 160, 1. 183). For the version published in Eynikayt, see I. Fefer, "Zeyere gebotn," Eynikayt, April 20, 1948, 3. 